Dirāsāt: Jurnal Manajemen dan Pendidikan Islam, Vol. 6, No. 2, Desember 2020: 158-181. ISSN (Online): 2550-1038, ISSN (Print): 2503-3506. Website: journal.unipdu.ac.id/index.php/dirasat/index. Dikelola oleh Program Studi Manajemen Pendidikan Islam (MPI) Program Pascasarjana Universitas Pesantren Tinggi Darul Ulum (Unipdu) Jombang Indonesia.

\title{
Persepsi Kepala Madrasah Ibtidaiyah terhadap Kinerja Supervisi Manajerial Pengawas Madrasah Ibtidaiyah Kota Yogyakarta
}

\author{
Wahyu Iskandar, Fia Alifah Putri \\ UIN Sunan Kalijaga Yogyakarta \\ Email: wiskandar921@gmail.com, fiaalifahputri24@gmail.com
}

\begin{abstract}
Abstrak: Supervisi manajerial adalah kegiatan yang mengakomodir kinerja madrasah. Supervisi manajerial secara teknis telah diatur dalam Peraturan Menteri Agama No 2 tahun 2012 dan Permendiknas No 12 Tahun 2007. Tujuan dasar penelitian ini untuk melihat bagaimana persepsi Kepala Madrasah Ibtidaiyah Al Islam Giwangan terhadap kinerja supervisi manajerial pengawas di kota Yogyakarta yang meliputi program perencanaan, pelaksanaan dan evaluasi. Penelitian lapangan (field research) ini berupaya menjelaskan data secara valid dan objektif mengenai persepsi Kepala Madrasah Ibtidaiyah Al Islam Giwangan terhadap kinerja pengawas kota Yogyakarta. Adapun metode yang digunakan adalah kombinasi atau (mix methode) yang sifatnya deskriptif. Metode ini merupakan metode gabungan antara metode kualitatif dan kuantitatif. Sementara model yang digunakan dalam penelitian ini adalah model concurrent embedded. Data yang dihasilkan bersifat deskriptif yang berupa kata-kata, ungkapan dan pendapat dari subjek penelitian secara lisan. Kemudian data diindeks dan dikategorisasikan menggunakan skala rating lajuan (rating scale). Adapun hasil penelitian ini menunjukkan bahwa kinerja supervisi manajerial dalam perencanaan program pengawas menurut persepsi kepala MI Al Islam Giwangan tergolong kategori sangat baik, sedangkan hasil rata-rata skor dalam perencanaan program supervisi manajerial berjumlah 100,00\%; kinerja supervisi manajerial dalam pelaksanaan program pengawas menurut persepsi Kepala Madrasah MI Al Islam Giwangan tergolong kategori sedang, sedangkan hasil rata-rata skor dalam pelaksanaan program supervisi manajerial berjumlah 69,12\%; kinerja supervisi manajerial dalam evaluasi program pengawas menurut persepsi kepala madrasah MI Al Islam Giwangan tergolong kategori sedang, sedangkan hasil rata-rata skor dalam evaluasi program supervisi manajerial berjumlah 75,00\%.

Kata kunci: Persepsi kepala madrasah, kinerja pengawas.
\end{abstract}

Abstract: Managerial supervision is an activity that accommodates the performance of madrasah. Managerial supervision is technically regulated in Regulation of the Minister of Religion No. 2 of 2012 and Permendiknas No. 12 (2007). The basic purpose of this study is to see how the Headmaster of Madrasah Ibtidaiyah Al Islam Giwangan's perceptions of the performance of managerial supervision of supervisors in the city of Yogyakarta that cover planning, implementation, and evaluation. This field research seeks to explain validly and objectively the data regarding the perceptions of the Headmaster of Madrasah Ibtidaiyah Al Islam Giwangan on the performance of supervisors in the city of Yogyakarta. The method used is a combination. This method is a combined method of qualitative and quantitative methods. Meanwhile, the model used in this research is the concurrent embedded model. The resulting data is descriptive in the form of words, expressions and opinions of research subjects orally. Then the data is indexed and categorized using a rate rating scale. The results of this study indicate that the performance of managerial supervision in the planning of the supervisory program according to the perception of the Headmaster of MI Al Islam Giwangan is in the very good category, while the average score in the planning of the managerial supervision program is 100,00\%; the performance of managerial supervision in the implementation of the supervisory program according to the perception of the Headmaster of the MI Al Islam Giwangan is in the moderate category, while the average score in the implementation of the managerial supervision program is $69.12 \%$; the performance of managerial supervision in the evaluation of the supervisory program according to the perception of the Headmaster of the MI Al Islam Giwangan is in the moderate 
category, while the average score in the evaluation of the managerial supervision program is $75,00 \%$.

Keywords: Headmaster of madrasah's perception, supervisory performance.

\section{Pendahuluan}

Sistem pendidikan di Indonesia pada tataran teori dan praktik sampai saat ini masih membutuhkan pola baru manajemen. ${ }^{1}$ Realitas ini telah disahuti dari berbagai elemen masyarakat, ${ }^{2}$ mahasiswa, ${ }^{3}$ praktisi, ${ }^{4}$ ilmuan, ${ }^{5}$ dan sebagainya. Oleh karenanya tidak sedikit dari mereka menawarkan ide baru dan saling berkolaborasi dalam mewujudkan pola manajemen konstruktif dalam rangka perbaikan sistem pendidikan di Indonesia. ${ }^{6}$ Problem akademik seperti ini harus disahuti dengan baik. Ditambah lagi dalam manajemen rasionalitas ${ }^{7}$ pada bidang pembangunan pendidikan "pemerataan" yang belum mapan di Indonesia dan menjadi tugas besar pemerintah. Maka dari itu para stakeholder pendidikan harus totalitas dan masif meramu misi besar dalam meningkatkan human resources development (sumber daya manusia) yang bermutu di Indonesia. ${ }^{8}$

Sejatinya dalam meningkatkan kualitas pendidikan pada upayanya tergantug dari polarisasi manajemen institusi yang dijalankan. Struktur manajemen yang baik akan berfungsi apabila para pimpinan dan sumber daya manusia di dalamnya berkualitas dan profesional. ${ }^{9}$ Pada porsi inilah suksesi

${ }^{1}$ Eko Supriyanto, Inovasi Pendidikan, Isu-Isu Pembelajaran, Manajemen, dan Sistem Pendidikan di Indonesia (Solo: Universitas Muhammadiyah Surakarta, 2003), 2.

${ }^{2}$ Munirwan Umar, "Manajemen Hubungan Sekolah dan Masyarakat dalam Pendidikan", Jurnal Edukasi 2, no. 1 (2016): 18-28.

${ }^{3}$ Susi Indriyani, Selvy Mardiana, "Pengaruh Penanganan Keluhan (Complaint Handling) Terhadap Kepercayaan dan Komitmen Mahasiswa Pada Perguruan Tinggi Swasta di Bandar Lampung", Jurnal Bisnis Darmajaya 2, no. 1 (2016): 1-13.

${ }^{4}$ Hujair Sanaky, "Paradigma Pembangunan Pendidikan di Indonesia Pasca Reformasi Antara Mitos Dan Realitas", Jurnal Ilmu ilmu Sosial Unisia 62 (2006): 1-18.

${ }^{5}$ Yudi Hartono, "Pendidikan dan Kebijakan Politik (Kajian Reformasi Pendidikan Di Indonesia Masa Orde Lama Hingga Reformasi”, Jurnal Sejarah dan Kemajuannya 6, no. 01 (2016): 35-45.

${ }^{6}$ Alia, Rahmi, "Implementasi Manajemen Peningkatan Mutu Berbasis Sekolah (MPMBS) di Smp Negeri 1 Palembang," (Masters Thesis, Universitas Islam Negeri Raden Fatah , 2019).

${ }^{7}$ Zainal Arifin, "Kepemimpinan Kiai Dalam Ideologisasi Pemikiran Santri Di PesantrenPesantren Salafiyah Mlangi Yogyakarta, Inferensi”, Jurnal Penelitian Sosial Keagamaan 9, no. 2 (2015): 351-372.

${ }^{8}$ Syafaruddin, Manajemen Mutu Terpadu Dalam Pendidikan Indonesia (Jakarta: Grasindo, 2003), 1. Lihat juga M. Asep Fathur Rozi, "Strategi Peningkatan Mutu Pendidikan Islam", Edukasi: Jurnal Pendidikan Islam 4, no. 2 (2016): 324-326. Lihat juga Wahyu Iskandar, Muhammad Yusuf, dan Annisa, "Prototipe Supervisi Pendidikan dan Kinerja Kepala Sekolah/Madrasah Dalam Rangka Peningkatan Mutu Pendidikan", Jurnal Islamic Education Manajemen 4, no. 2 (2019): 163-180.

${ }^{9}$ Mochamad Iskarim, "Rekrutmen Pegawai: Starting-Point menuju Kinerja Organisasi yang Berkualitas dalam Perspektif Manajemen Sumber Daya Manusia dan Islam”, Jurnal Manajemen Pendidikan Islam 2, no. 2 (2012): 307-327. Lihat juga Siti Rokhmi Lestari, "Manajemen Pengembangan Dosen Sebagai Upaya Meningkatkan Mutu Sekolah Tinggi Pariwisata Ampta 
bidang pendidikan madrasah dan sekolah akan berjalan dengan baik. Abadi menuturkan bahwa setidaknya ada basis inti yang bekerja merawat manajemen yang dilihat dari empat unsur berkualitas, yakni guru, kepala madrasah, pengawas dan masyarakat. Abadi juga mengatakan bahwa madrasah di Indonesia pada perjalanannya sangat potensial melakukan gebrakan baru pada sistem manajemen, ditambah kemampuan lebihnya dalam mencetak generasi bangsa yang religius-nasionalis. ${ }^{10}$ Madrasah dalam tataran konseptual memiliki karakter tersendiri sebagai satuan pendidikan yang berada dilingkungan kementerian agama. Pengembangan keislaman menjadi ciri khas madrasah. ${ }^{11}$ Dengan ciri keislaman ini, madrasah telah lama mengembangkan dan melaksanakan program-program pendidikan yang disesuaikan dengan karakteristik potensi dan kebutuhan peserta didik. Dalam mendapatkan madrasah yang berkualitas, maka sumber daya manusia sangatlah penting. Hal yang dimaksud dengan sumber daya manusia, terkandung aspek kompetensi, ketrampilan, kemampuan, sikap, perilaku, motivasi dan komitmen. Dalam bidang pendidikan, jenis sumber daya manusia berdasarkan tugas pokoknya terdiri atas beberapa jenis, yaitu tenaga teknis, tenaga administratif dan tenaga penunjang. Selanjutnya dalam PP 38/1992 tentang tenaga kependidikan ditegaskan pengelompokannya menjadi (1) tenaga pendidik, (2) pengelola, (3) pengawas, (4) laboran, (5) teknisi sumber belajar, (6) peneliti dan (7) penguji dan pengawas. ${ }^{12}$

Pengawas atau supervisor juga sangat berkepentingan terhadap quality performance (kinerja yang berkualitas) dalam pengelolaan Sekolah dan Madrasah. ${ }^{13}$ Istilah yang biasa digunakan Kementerian Pendidikan Nasional supervisor adalah seorang inspektorat dan penilik yang menjalankan fungsi sebagai "Controlling". 14 Sementara menurut Syafaruddin bahwa supervisor adalah orang yang secara aktif mengawasi instansi. ${ }^{15}$ Pendapat lain menurut Ary H Gunawan supervisor adalah orang yang membimbing dan membantu guru dalam bidang intruksional. ${ }^{16} \mathrm{Di}$ tingkat pusat fungsi pengawasan dilaksanakan oleh Inspektur Jenderal, di tingkat Provinsi dan di tingkat

Yogyakarta”, Jurnal Media Wisata 12, no. 2 (2014): 87-101. Lihat juga Malayu S Hasibuan,. Manajemen Sumber Daya Manusia. Cetakan Ketiga (Jakarta: Bumi Aksara, 2001).

${ }^{10}$ Nur Abadi, Dkk. Pedoman Supervisi Pengawas Madrasah dan Pengawas PAI Pada Sekolah (Semarang: Kantor Wilayah Kementerian Agama Provinsi Jawa Tengah, 2012), 2.

${ }^{11}$ Lihat Nurcholis Majid, Masyarakat Religius: Membumikan Nilai-Nilai Islam Dalam Kehidupan Masyarakat (Jakarta: Paramadina, 2000), 96-101. Lihat juga Sri Haningsih, "Peran Strategis Pesantren, Madrasah dan Sekolah Islam di Indonesia", Jurnal El Tarbawi 1, no. 1 (2008): 27-39.

${ }^{12}$ Fatah Nanang, Landasan Manajemen Pendidikan (Bandung: Remaja Rosdakarya, 2004), 13.

${ }^{13}$ Wahyu Iskandar, dan Imam Machali, "Persepsi Kepala Madrasah Terhadap Kinerja Supervisi Manajerial Pengawas Madrasah Ibtidaiyah Kota Yogyakarta", Al-Idarah: Jurnal Kependidikan Islam 10, no. 1 (2020): 76-93.

${ }^{14}$ Kadim Masaong, Supervisi Pembelajaran dan Pengembangan Kapasitas Guru (Bandung:Alfabeta, 2013), 1.

${ }^{15}$ Syafaruddin Dkk, Administrasi Pendidikan (Medan:Perdana Publishing, 2016), 1.

${ }^{16}$ Ary H Gunawan, Administrasi Sekolah (Jakart: Rinekacipta, 2011), 93. 
Kabupaten/Kota supervisor lebih familiar disebut dengan pengawas. Pengawas sebagai tenaga kependidikan memiliki peran membina kemampuan profesional tenaga pendidik dan kepala madrasah dalam rangka meningkatkan kinerja Madrasah. Peran pengawas madrasah sangat dibutuhkan dalam rangka peningkatan kualitas pendidikan madrasah dan telah diperkuat kedudukanya melalui peraturan Menteri Agama No. 2 tahun 2012 dan peraturan Menteri No.31 tahun 2014 dalam melaksanakan tugas dan fungsinya. Pengawas diharuskan untuk memiliki kompetensi tersebut meliputi tiga kompetensi pokok yaitu supervisi akademik, evaluasi pendidikan, penelitian dan pengembangan. ${ }^{17}$ Peranan lainnya pengawas juga diharuskan untuk memberi program supervisi ${ }^{18}$ yang disusun untuk meningkatkan kualitas Sekolah/Madrasah yang dibinanya. Supervisi adalah sejumlah aktivitas yang mengkoordinir kinerja lembaga dalam rangka meningkatkan mutu dalam manajerial dan pembelajaran. Supervisi juga memiliki interest (kepentingan) dalam mengusahakan dan meningkatkan kemampuan kepala Madrasah dan guru. ${ }^{19}$

Tuntutan profesionalitas di atas mewajibkan pengawas untuk memenuhi kompetensi sebagai supervisor manajerial yang merupakan tugas pokok pengawas madrasah. Sebagai supervisor manajerial, berkewajiban membantu kepala madrasah agar mencapai madrasah yang efektif. Selain itu, pengawas memiliki peran evaluator pendidikan, Di mana pengawas harus memiliki kompetensi mengevaluasi kinerja Kepala madrasah. Hal ini demi meningkatkan mutu pendidikan di madrasah yang dibinanya. Di sisi lain, tuntutan pemenuhan kompetensi penelitian dan pengembangan juga menjadi kendala oleh pengawas karena berbagai sebab, antara lain kemampuan meneliti yang masih rendah, keterbasan anggaran, tidak adanya pembinaan khusus tentang penelitian dan pengembangan. Kondisi ini menjadi kendala bagi para pengawas untuk memenuhi tuntutan kompetensi sebagaimana diatur dalam Permendiknas Nomor 12 Tahun 2007 khususnya mengenai Kompetensi Penelitian dan Pengembangan.

Kecenderungan yang terjadi saat ini adalah rendahnya kemampuan meneliti oleh pengawas terhadap madrasah yang dibinanya dan berimplikasi terhadap peningkatan profesionalime guru madrasah. Ditambah lagi dewasa ini kegiatan supervisi oleh sebagian supervisor (pengawas) masih berorientasi pada pengawasan (kontrol) dan obyek utamanya adalah administrasi, sehingga suasana kemitraan kepala madrasah, guru dan supervisor kurang tercipta bahkan guru secara psikologis merasa terbebani dengan pikiran untuk dinilai dan kepala madrasah merasa diperintah dan ditekan. Padahal kegiatan supervisi

\footnotetext{
${ }^{17}$ Kementerian Agama RI Direktorat Jenderal Pendidikan Islam, Pedoman Pembinaan Pengawas Madrasah Dan Pengawas Pendidikan Agama Islam Pada Sekolah, 2014.

${ }^{18}$ Lihat dalam Piet A. Sahertian, Konsep Dasar dan Teknik Supervisi Pendidikan dalam Rangka Pengembangan Sumber Daya Manusia (Jakarta: Rineka Cipta, 2008), 18. Lihat juga dalam Dadang Suhardan, Supervisi Profesional (Bandung: Alfabeta, 2010), 48.

${ }^{19}$ Dadang, Supervisi Profesional, 28.
} 
akan efektif jika perasaan terbebas dari berbagai tekanan diganti dengan suasana pemberian pelayanan serta pemenuhan kebutuhan yang bersifat informal. ${ }^{20}$

Mencermati konteks di atas peneliti menemukan penelitian yang relevan bahwa pada data 2013 tercatat data valid dalam penelitian Yustiani mengenai kinerja pengawas di Yogyakarta. Data ini dimuat di jurnal Analisa bahwa kinerja pengawas Daerah Istimewa Yogyakarta termasuk pengawas kota Yogyakarta dalam pelaksanaan program kepengawasan tergolong dalam kategori baik dengan skor 76,25. Ditambah lagi dengan persepsi kepala madrasah bahwa persepsi kepala madrasah terhadap kinerja pengawas memperoleh nilai rerata 78,12 dengan kategori baik. Nilai tertinggi yakni 29 dengan rerata 90,63 adalah kinerja pengawas berkenaan dengan melaksanakan pembinaan madrasah dalam persiapan akreditasi. ${ }^{21}$

Berangkat dari problem di atas peneliti ingin membentangkan penelitian terkait supervisi manajerial di Daerah Istimewa kota Yogyakarta. Di mana dalam pra penelitiaan peneliti melacak pengawas dari kantor kemenag kota Yogyakarta yang mengawasi tiga madrasah ibtidaiyah di kota Yogyakarta, yakni MIN 1 Yogyakarta, MI Al-Islam Giwangan Yogyakarta dan MI Nurul Ummah Kota gede. Namun pada penelitian ini peneliti memberikan titik fokus pada persepsi kepala MI Al-Islam Giwangan yakni Ibu Retna Zumiatun S.TP terhadap kinerja supervisi manajarial Ibu Ratini M, Si sebagai pengawas MI Al-Islam Giwangan. Di mana masalah yang akan diangkat adalah bagaimana persepsi kepala MI Al-Islam Giwangan terhadap perencanaan program supervisi manajerial pengawas Madrasah Ibtidaiyah Kota Yogyakarta, bagaimana persepsi kepala MI Al-Islam Giwangan terhadap pelaksanaan program supervisi manajerial pengawas madrasah ibtidaiyah kota Yogyakarta dan bagaimana persepsi kepala MI Al-Islam Giwangan terhadap evaluasi program supervisi manajerial pengawas madrasah ibtidaiyah kota Yogyakarta.

\section{Metode Penelitian}

Penelitian lapangan (field research) ini akan menjelaskan secara valid dan objektif mengenai persepsi kepala MI Al-Islam Giwangan terhadap kinerja pengawas kota Yogyakarta. Adapun metode yang digunakan adalah kombinasi atau (mix methode) yang sifatnya deskriptif. Metode ini merupakan metode gabungan antara metode kualitatif dan kuantitatif. Sementara model yang digunakan dalam penelitian ini adalah model concurrent embedded. Model embedded adalah model penelitian dengan mengkombinasikan data kualitatif dan kuantitatif secara bersama sama (simultan). Data yang dihasilkan adalah bersifat deskriptif yaitu berupa kata-kata, ungkapan dan pendapat dari subjek penelitian secara lisan. Kemudian data di indeks dan di kategorisasikan

\footnotetext{
${ }^{20}$ Ibid., 4.

${ }^{21}$ Yustiani, "Kinerja Pengawas Madrasah di Propinsi Daerah Istimewa Yogyakarta," Jurnal Analisa 20, no. 1 (2013): 115-30.
} 
menggunakan skala rating lajuan atau rating scale. ${ }^{22}$ Kurang lebih penggalian data seperti penjelasan gambar dibawah ini:

Gambar 1

Struktur data penelitian

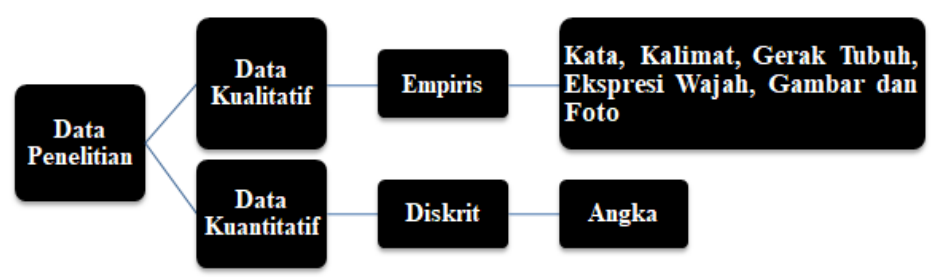

\section{Hasil dan Pembahasan}

Setiap penelitian membutuhkan teori untuk membedah, menganalisis dan menjawab problema yang menjadi titik permasalahan. Penggunaan teori dapat dilihat dari perspektif mana permasalahan itu disoroti. Maka dalam penelitian ini, untuk menjawab persoalan yang telah ditemui sebagai berikut. Kata persepsi dari bahasa Latin, perceptio, atau percipio $^{23}$ yang secara makna adalah tindakan menyusun, mengenali, dan menafsirkan informasi sensoris guna memberikan gambaran dan pemahaman tentang keadaan. Persepsi meliputi semua sinyal dalam sistem saraf, yang merupakan hasil dari stimulasi fisik atau kimia dari organ pengindra. ${ }^{24}$ Makna lain dari persepsi menurut Henry Clay Lindgren bahwa "perception is viewed as the medical $s$ the mediating processes that are initialed by sensation" atau persepsi dipandang sebagai proses mediasi medis yang diawali dengan sensasi. ${ }^{25}$

Para ahli seperti Bimo Walgito menuturkan bahwa persepsi adalah suatu proses yang di dahului oleh penginderaan yaitu merupakan proses yang berwujud diterimanya stimulus oleh individu melalui alat indera atau juga disebut proses sensoris. ${ }^{26}$ Sedangkan Menurut Slameto menurutnya persepsi proses yang menyangkut masuknya pesan atau informasi kedalam otak manusia, melalui persepsi manusia terus menerus mengadakan hubungan dengan lingkungannya. Hubungan ini dilakukan lewat inderanya, yaitu indera

\footnotetext{
${ }^{22}$ Imam Machali, Metode Penelitian Kuantitatif (Yogyakarta: Prodi Manajemen Pendidikan Islam Bekerjasama Dengan Perkumpulan Program Studi Manajemen Pendidikan Islam (PPMPI), 2018), 49-50.

${ }^{23}$ Kamus Webster, America's Most-trusted online dictionary. Link https://www.merriamwebster.com/

${ }^{24}$ Tim Pusat Bahasa Departemen Pendidikan Nasional, Kamus Besar Bahasa Indonesia (Jakarta: Balai Pustaka, 2003), 863.

${ }^{25}$ Lindgren Henry Clay, An Introduction as Social Psychology (United States Of America, 1981), 292.

${ }^{26}$ Lihat Bimo Walgito, Psikologi Sosial: Suatu Pengantar (Yogyakarta: Andi Offset, 2001), 54.
} 
pengelihat, pendengar, peraba, perasa, dan pencium. ${ }^{27}$ Menurut Robbins yang mendeskripsikan bahwa persepsi merupakan kesan yang diperoleh oleh individu melalui panca indera kemudian di analisa (diorganisir), di intepretasi dan kemudian di evaluasi, sehingga individu tersebut memperoleh makna. ${ }^{28}$

Berdasarkan berbagai makna dan intepretasi persepsi diatas, secara umum dapat disimpulkan bahwa persepsi adalah pemberian pandangan, makna, intepretasi dan berbagai varian sensasi yang diterima oleh individu. Pada prosesnya pembentukan persepsi menurut Walgito dapat digambarkan seperti dibawah ini.

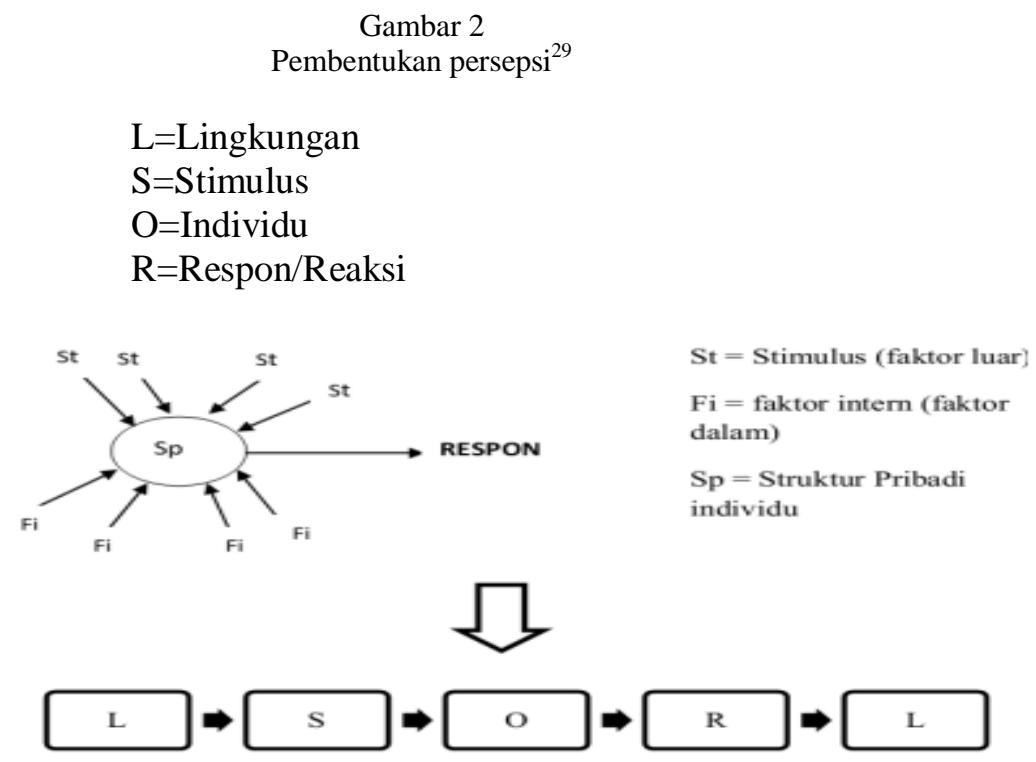

Pada konteks yang berbeda kepala madrasah dalam kepemimpinannya merupakan aspek paling penting dalam menentukan berhasil tidaknya suatu organisasi, karena menyangkut perilaku seorang pemimpin dalam rangka mempengaruhi para pegawai/karyawannya, sehingga para pegawai mau bekerjasama dalam rangka mewujudkan tujuan organisasi. Kepemimpinan berfungsi sebagai tindakan yang dilakukan pemimpin dalam upaya menggerakkan bawahan agar berbuat sesuatu guna menyukseskan program-

\footnotetext{
${ }^{27}$ Lihat Slameto, Belajar dan Faktor-Faktor Yang Mempengaruhinya (Jakarta: Rineka Cipta, 2010), 102-104.

${ }^{28}$ Zulia Hanum, "Pengaruh Persepsi Pengusaha Kecil Atas Informasi Akuntansi Keuangan Terhadap Keberhasilan Perusahaan," Jurnal Riset Akuntansi dan Bisnis 13, no. 2 (2013): 217 250.

${ }^{29}$ Hadi Suprapto Arifin, dkk, “Analisis Faktor Yang Mempengaruhi Persepsi Mahasiswa Untirta Terhadap Keberadaan Perda Syariah Di Kota Serang," Jurnal Penelitian Komunikasi Dan Opini Publik 21, no. 1 (2017): 88-101.
} 
program kerja yang telah dirumuskan. ${ }^{30}$ Adapun Menurut Covey dalam bukunya The Principle Centered Leadership seorang pemimpin yang efektif memiliki prinsip-prinsip dalam membangun organisasinya. Prinsip adalah bagian dari kondisi, kesadaran dan suara hati. Prinsip dapat menimbulkan kepercayaan dan merupakan kompas yang menunjukkan arah, panduan yang tidak berubah. $^{31}$

Sementara Menurut Sujanto kepemimpinan yaitu perilaku seorang pemimpin untuk mengarahkan, mempengaruhi, dan menjelaskan kepada bawahan, berinisiasi dan memelihara kekompakan kelompok, sikap konsisten agar setiap anggota dapat memberikan sumbangan secara efektif kepada organisasi demi tercapainya tujuan. ${ }^{32}$ Sementara, istilah supervisi berasal dari dua kata yaitu "super" dan "vision". Dalam Webstr's New Word Dictionary istilah super berarti "higher in rank or position than, superior to (superintendent), greater or better than others". Sedangkan dalam buku yang sama kata vision berarti "the ability to perceive something not actually visible, as through mental acutness or keen foresight". Artinya seorang supervisor (pengawas) adalah seorang profesional, ketika ia menjalankan tugasnya, ia bertindak atas dasar kaidah-kaidah ilmiah untuk meningkatkan mutu pendidikan. ${ }^{33}$ Untuk menjalankan supervisi diperlukan kelebihan yang dapat melihat dengan tajam terhadap permasalahan peningkatan mutu pendidikan, menggunakan kepekaan untuk memahaminya dan tidak hanya sekedar menggunakan penglihatan mata biasa, sebab yang diamatinya bukan masalah kongkrit yang tampak, melainkan memerlukan insight dan kepekaan sikologis. $^{34}$

\section{Persepsi Kepala Madrasah terhadap Perencanaan Program Supervisi Manajerial Pengawas Madrasah Ibtidaiyah}

Madrasah Ibtidaiyah Al Islam Giwangan termasuk madrasah yang berkembang pesat di Kota Yogyakarta pada tingkat dasar. Madrasah ini dibangun sebagai bukti pengembangan SDM dari lembaga yayasan panti asuhan di kota Yogyakarta. Yayasan panti asuhan Al Islam sendiri sangat terlibat pada proses berdirinya MI Al Islam Giwangan. Berawal dari kesadaran bahwa anak anak panti harus mendapatkan pendidikan formal dari tingkat dasar. Untuk itulah MI Al Islam Giwangan perlu dibangun dengan dasar optimalisasi yayasan Al

\footnotetext{
${ }^{30}$ J. M. Howell, and B.J. Avolio, "Transformational Leadership, Transactional Leadership, Locus of Control, and Support for Innovation: Key Predictors of Consolidated-Business-Unit Performance", Journal Of Applied Psychology 78, no. 6 (1993).

${ }^{31}$ S. R. Covey, The 7 Habits of Highly Effective People (Jakarta: Gramedia, 1997), 26.

${ }^{32}$ Bedjo Sujanto, Manajemen Pendidikan Berbasis Sekolah: Model Pengelolaan Sekolah di Era Otonomi Daerah (Jakarta: Sagung Seto, 2009), 68.

${ }^{33}$ Jaka Waluya, "Supervisi Pendidikan Pada Sekolah Dasar", Pedagogik: Jurnal Pendidikan Guru Sekolah Dasar 1, no. 1 (2013): 32-42.

${ }^{34}$ Mochamad Selamet, "Pengaruh Kompetensi Supervisi Manajerial dan Supervisi Akademik Pengawas Sekolah terhadap Kinerja Guru', Jurnal Ilmiah Mahasiswa Pascasarjana Administrasi Pendidikan 2, no. 1 (2014): 73-86.
} 
Islam. ${ }^{35}$ Meskipun MI Al Islam berdiri secara independen juga tidak terlepas dari pengawasan Kementrian Agama Kota Yogyakarta. ${ }^{36}$ Kepala madrasah MI Al Islam Giwangan sadar betul bahwa madrasah formal tidak etis bila dibangun berdasarkan otoritarianisme yayasan dengan memisahkan diri terhadap kebijakan pemerintah atau Kemenag. Kendipun demikian MI Al Islam sudah menjadi lembaga formal di Kota Yogyakarta masih banyak yang harus di penuhi sebagai lembaga formal. Termasuk pada aspek peningkatan mutu, untuk itulah pada Tahun 2014 kemarin kemenag sudah mengutus pengawas sebagai bentuk pemantuan dan perkembangan dari MI Al Islam Sendiri. Pada konteks ini MI Al Islam Giwangan mendapatkan pengawas yang sama dengan MIN 1 Kota Yogyakarta yakni Ibu Ratini. Tahapan pengawasan mulai terlaksana setelah MI Al Islam Giwangan mendapatkan Legalitas dari Kemenag Kota Yogyakarta.

Pelaksanaan supervisi di MI Al Islam yang dilakukan Ibu Ratini pada tahun 2019 mendapatkan kritikan dari pihak madrasah. Kritikan ini tidak langsung di sampaikan kepada Ibu Ratini tetapi secara rapat tertutup pihak madrasah meginginkan kinerja yang baik pada pelaksanaan supervisi. Mengingat MI Al Islam adalah lembaga yang masih terbilang belia yang harus diperhatikan. Adapun pada bagian ini kepala madrasah MI Al Islam Giwangan berkomentar:

"Pengawas kurang konsisten mas pada pelaksanan, beliau hanya berfokus pada perencanaan. Terbukti pada semester kemarin pengawas hanya fokus kepada perencanaan program seperti, penyusunan program tahunan, perencanaan program pembinaan kepala, penilaian kerja kepala dan rencana bimbingan konseling kepala. Saya merasa puas pada penyusunan program namun pada pelaksanaan belum optimal. Saya juga kurang paham apakah ibu Ratini sediri tidak memprioritaskan kami karena masih madrasah baru atau bisa jadi karena sdm seperti guru guru belum ada satupun yang ASN ditempat kami.",37

Perencanaan program supervisi manajerial pengawas bisa dikatakan cukup dominan dalam mempertihakan MI Al Islam Giwangan bila dilihat dari kometar diatas. Hal ini seharusya terus dipertahankan pengawas mengingat MI Al Islam Giwangan masih baru 'belia' yang butuh pematauan lebih dari pengawas. Pada prinsipnya peran pengawas memang harus totalitas mulai dari perencanaan sampai evaluasi. Prinsip ini juga dikemukakan oleh para ahli pedidikan seperti Suharsimi arikunto bahwa prinsip dalam pengawasan harus berdasarkan asas menghargai, tolong menolong, terecana, terus menerus dan

\footnotetext{
${ }^{35}$ Wawancara dengan Retna Zumiatun, Kepala Madrasah MI Al Islam Pada Tanggal 5 Februari Pukul 09.00 WIB.

${ }^{36}$ Lihat Kantor Kemenag Kota Yogyakarta Online Bidang Pendidikan Madrasah. Link. https://yogyakartakota.kemenag.go.id/unit-kerjaa/bidang-pendidikan-madrasah/madrasah-negeri.

${ }^{37}$ Wawancara dengan Retna Zumiatun, Kepala Madrasah MI Al Islam Pada Tanggal 5 Februari Pukul 09.20 WIB.
} 
sistematis. ${ }^{38}$ Prinsip inilah yang seharusya dipegang teguh oleh seluruh pengawas agar tercipta pendidikan yang selama ini diharapkan.

Berbicara tentang proses kepegawasan dalam perencanaan program supervisi manajerial di MI Al Islam Giwangan tidak terlepas dari pertanyaan sebelumya bahwa perencanaan yang harus di prioritaskan berangkat dari 6 indikator: (1) pengawas memiliki program pengawasan tahunan, (2) pengawas memiliki program pembinaan kepala madrasah, (3) pengawas memiliki program pemantauan $8 \mathrm{SNP}$, (4) Pengawas memiliki program penilaian kinerja kepala madrasah, (5) pengawas memiliki RPBK rencana pelaksanaan bimbingan konseling (6) pengawas memiliki program bimbingan kepala madrasah di KKKS/MKKS. Persepsi yang harus disampaikan oleh kepala madrasah terhadap kinerja pegawasnya pada aspek perencanaan menjadi penting untuk diketahui. Pada pembahasan ini kepala madrasah menganggap perecanaan penting sebelum terlaksananya program kepengawasan. Perencanaan program tahunan, pembinaan kepala madrasah dan pemantauan delapan SNP telah terencana dengan sistematis oleh pengawas di MI Al Islam Giwangan. Hal ini disampaikan oleh Ibu Retna sebagai kepala madrasah MI Al Islam Giwangan sebagai berikut.

"Pengawasan manajerial berlangsung selama seminggu mas. Biasanya ibu Ratini menyampaikan perencanaannya si hari pertama. pada proses penyusunan program pemantauan SNP menjadi rencana inti oleh Ibu Ratini mas, mengingat MI kami sendiri masih belum optimal pada peningkatan akreditasi. Beliau selalu menyempatkan mengabari saya ketika hendak mensupervisi. Dan yang paling awal di sampaikan adalah tentang pemantauan delapan SNP dan akreditasi. Untuk proses akreditasi biasanya beliau meminta kepada guru dan staf untuk selalu meningkatkan kompetensi masing. Dan saya tentunya di perintahkan untuk selalu memenuhi kebutuhan madrasah seperti sarana prasarana dan lainnya.",39

Mencermati hal diatas senada dengan ruang lingkup beban kerja pengawas Madrasah yang merujuk pada PMA No. 2 Tahun 2012 tentang Pengawas Madrasah dan Pengawas Pendidikan Agama Islam pada Sekolah yang kemudian di polarisasi kembali oleh PMA No. 31 tahun 2013 tentang Perubahan Atas PMA No. 2 Tahun 2012 pasal 1 ayat 3 adalah melaksanakan supervisi menejerial dan supervisi akademik. Kemudian kewajiban pengawas harus memiliki perencanaan program semsester dan tahunan. Pada bagian program dilaksanakan selama sekurang kurangnya 7 hari atau satu minggu

\footnotetext{
${ }^{38}$ Suharsimi Arikunto dan Lia Yuliana, Manajemen Pendidikan (Yogyakarta: Aditya Media, 2008), 379.

${ }^{39}$ Wawancara dengan Retna Zumiatun, Kepala Madrasah MI Al Islam Pada Tanggal 5 Februari Pukul 09.30 WIB.
} 
selanjutnya menyampaikan rencana program yang akan berjalan di hari pertama pengawasan. $^{40}$

Perencanaan di MI Al Islam Giwangan menurut persepsi kepala madrasah MI Al Islam Giwangan berjalan dengan baik dilihat dari 3 indikator yang dilaksanakan oleh pengawas seperti pemantauan delapan SNP, rencana program semester dan tahunan sampai instrumen pengawasan. Adapun seperti bimbingan konseling dan rencana pelaksanaan bimbingan KKKM/KKKS masih masih belum optimal. Hal ini senada dengan penuturan kepala madrasah MIN 1 Kota Yogyakarta sebelumnya bahwa KKKM/KKKS masih pada tahap perencanaan. Ini dibuktikan dengan adanya kelompok grup WhatsApp $\mathrm{KKKM} / \mathrm{KKKS}$. Pembicaraan didalamnya hanya bersifat nonformal atau temu ramah online. Pada bagian tertentu terkadang tidak jarang para kepala madrasah meminta agar progam bimbingan KKKM/KKKS tidak berhenti di grup WA melainkan pelatihan kelompok kerja kepala madrasah. Perencanaan KKKM/KKKS dan program konseling sudah seharusnya juga diprioritaskan oleh pengawas. Perencanaan KKKM/KKKS dan program konseling sangat diperlukan oleh para kepala madrasah meskipun keduanya sangat sedikit untuk mempengaruhi akreditasi madrasah. Keberadaan seharusnya KKKM/KKKS memiliki kontribusi yang signifikan jika benar benar terlaksana dengan baik. Hal ini disampaikan oleh Fitra bahwa manajemen kelompok kerja memberikan kontribusi yang nyata bagi para pimpinan lembaga, mulai dari kemampuan beradaptasi, ruang diskusi, pemecahan masalah sampai kepada peningkatan kualitas kinerja para pimpinan pada tataran manajemen. ${ }^{41}$

Sebagai kepala madrasah tentunya setiap aspek perencanan diharapkan secara utuh oleh pengawas demi keberlangsungan pendidikan yang diharapkan. Adapun komentar kepala madrasah pada aspek perencanaan program KKKM/KKKS sebagai berikut.

"Pada mulanya saya sangat berharap mas ada sebuah pelatihan diskusi antar kepala madrasah. Melalui program kelompok kerja kepala madrasah. Saya tidak bisa berburuk sangka, bisa jadi ibu Ratini terlalu sibuk sehingga kelompok kerja kepala madrasah tidak optimal dijalankan. Atau bisa jadi karena jumlah MI di Kota Yogyakarta hanya berjumlah 4 madrasah. Jadi tidak perlu di aktifkan pada program KKKM/KKKS. Saya berharap sebagai kepala madrasah harusnya program ini ada dan terencana. Karena bukan hanya momen silatuhami antar kepala madrasah saja yang di dapat namun kerja sama yang di bangun antar MI yang paling penting saya rasa". 42

\footnotetext{
${ }^{40}$ Nurmawati, "Peran Pengawas dalam Mempersiapkan Akreditasi Madrasah", Semdi Unaya 3, no. 1 (2019): 950-963.

${ }^{41}$ Reni Ayu Fitra, "Pelaksanaan Fungsi Kelompok Kerja Kepala Sekolah Dasar Negeri Kecamatan Koto Tangah Kota Padang”, Jurnal Bahana Manajemen Pendidikan 1, no. 1 (2013): 19-31.

${ }^{42}$ Wawancara dengan Retna Zumiatun, Kepala Madrasah MI Al Islam Pada Tanggal 5 Februari Pukul 09.30 WIB.
} 
Pernyataan di atas menimbulkan reaksi kepala madrasah bahwa tugas kepala madrasah bukan hanya mampu memanejemen MI yang dikelolanya, namun para kepala madrasah juga berhak mendapatkan kegiatan yang menghasilkan kemampuan pada pengambilan keputusan dan kebijakan kepala madrasah melalui penyusunan program seperti kelompok kerja kepala madrasah.

Perencanaan yang dilakukan oleh ibu Ratini di MI Al Islam Giwangan secara teknis sudah sudah terlaksana sebagaimana mestinya. Secara bertahap perencanaan program supervisi manajerial terencana dengan baik. Terlihat dari semua indikator perencanaan yang harus dilakukan dimiliki oleh Ibu Ratini sebagai pengawas yang profesional. Meskipun dari 6 Indikator kerja pada perencaan program belum optimal pada pelaksanaannya. Dalam hal ini peneliti mendapatkan data laporan pengawas Kota Yogyakarta yakni Ibu Ratini pada perencanaan programnya di MI Al Islam Giwangan. Terlihat pada indikator kinerja perencanaan program supervisi manajerial terisi dengan skor tertinggi atau 4. Selain simpulan yang dipertegas secara kualitatif akan diperjelas juga melalui data kuantitatif peneliti sebagai penguat data yang telah di dapatkan. Pengukuran ini tetap sama melihat persepsi kepala madrasah terhadap kinerja pengawas pada perencanaan program. Adapun hasil penyebaran angket yang di lakukan kepada kepala madrasah MI Al Islam Giwangan kota Yogyakarta.

Pernyataan angket ada 4 kriteria jawaban yang harus di isi oleh responden, yakni sangat tidak setuju, tidak setuju, setuju dan sangat setuju. Bila di presentasekan dengan angka maka kategorisasinya buruk sekali, buruk, sedang, baik sekali. Berikut presentasenya.

Tabel 1

Hasil persentase jawaban Kepala Madrasah MI Al Islam terhadap perencanaan pengawas

\begin{tabular}{|l|l|c|c|}
\hline \multirow{2}{*}{ No } & \multicolumn{1}{|c|}{ Item Pernyataan } & \multicolumn{2}{c|}{ MI Al Islam Giwangan } \\
\cline { 3 - 4 } & \multicolumn{1}{|c|}{$\begin{array}{c}\text { Jawaban } \\
\text { Alternatif }\end{array}$} & Persentase \\
\hline 1 & Pengawas memiliki program pengawasan tahunan & 4 & $16,67 \%$ \\
\hline 2 & $\begin{array}{l}\text { Pengawas memiliki program pembinaan kepala } \\
\text { madrasah }\end{array}$ & 4 & $16,67 \%$ \\
\hline 3 & $\begin{array}{l}\text { Pengawas memiliki program pemantauan delapan } \\
\text { SNP }\end{array}$ & 4 & $16,67 \%$ \\
\hline 4 & $\begin{array}{l}\text { Pengawas memiliki program penilaian kinerja } \\
\text { kepala madrasah }\end{array}$ & 4 & $16,67 \%$ \\
\hline 5 & $\begin{array}{l}\text { Pengawas memiliki Rencana pengawasan } \\
\text { Bimbingan konseling (RPBK) dan rencana } \\
\text { pengawasan Manajerial (RPM) }\end{array}$ & 4 & $16,67 \%$ \\
\hline 6 & $\begin{array}{l}\text { Pengawas memiliki program bimbingan kepala } \\
\text { madrasah di KKKS/MKKS }\end{array}$ & 4 & $16,67 \%$ \\
\hline Jumlah & \multicolumn{2}{|c|}{24} & $100,00 \%$ \\
\hline
\end{tabular}




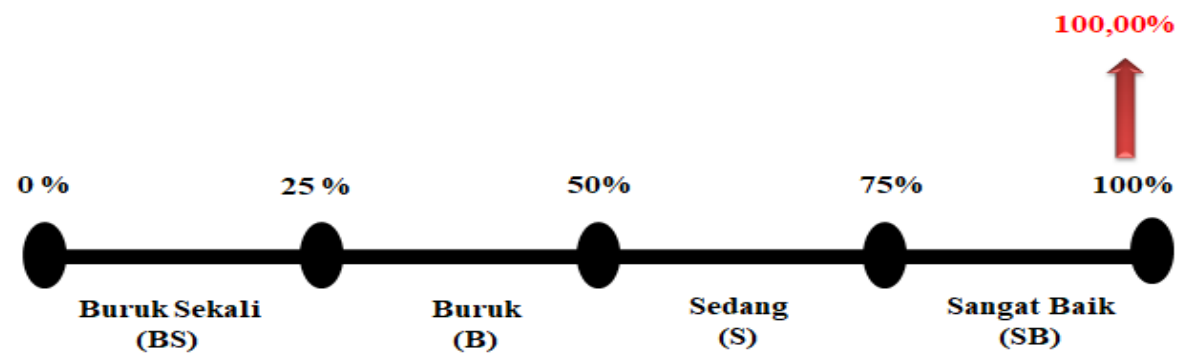

\section{Persepsi Kepala Madrasah terhadap Pelaksanaan Supervisi Manajerial Pengawas}

Pelaksanaan supervisi manajerial di $\mathrm{MI}$ Al Islam sedikit berbeda dari pengawasan di MIN 1 Kota Yogyakarta. Kepala madrasah MI Al Islam melihat hal tersebut dengan penuh kewajaran. Mengingat tugas pengawas yang begitu banyak ditambah ketika supervisi manajerial yang suharusnya dilaksanakan di MI Al Islam dengan kebetulan pengawas Kota Yogyakarta yakni Ibu Ratini sering mendapat undangan rapat dari Kemenag dan Dinas Pendidikan kota Yogyakarta. Hal ini terlacak dari penyampaian pengawas sendiri ketika Pra penelitian di Kemenag. Adapun penuturannya sebagai berikut.

"Saya sudah menghubungi pihak MI Al Islam mas, pelaksanaan supervisi manajerial biasanya saya lakukan di akhir semester, biasanya seminggu atau tiga hari waktu pelaksanaan. Tapi berhubung saya banyak mendapatkan undangan rapat di dinas pendidikan dan kemenag jadi saya cancel dulu supervisi di Al Islam, ya mungkin nanti saya jika sempat hanya mempersiapkan akreditasi saja dan memantau dokumen administrasi." ${ }^{43}$

Mengomentari penuturan di atas bahwa pengawas kota Yogyakarta belum totalitas dalam pengawasannya di MI Al Islam karena situasi tertentu. Pada konteks ini seharusnya pengawas kembali pada prinsip utama supervisi yakni supervisi harus konstruktif, kreatif dan profesional termasuk dalam memanajemen waktu. Demikian agar menjaga keseimbangan antara prinsip fundamental pengawas dan sikap dari pihak madrasah. ${ }^{44}$ Menurut keterangan kepala madrasah MI Al Islam bahwa pengawas pada program manajerial lebih mengedepankan administrasi madrasah seperti pemaantauan SNP dan membantu merumuskan visi misi madrasah, untuk hal hal yang mengenai pembinaan, konseling dan pelatihan dilihiat dari tahun ke tahun belum menemukan kosistensi menurut Retna Zumiatun kepala madrasah MI Al Islam.

\footnotetext{
${ }^{43}$ Wawancara dengan Ibu Ratini selaku pengawas kota Yogyakarta pada Pra Penelitian di Kemenag Kota Yogyakarta. Rabu 20 November 2019 pukul 11.00 WIB.

${ }^{44}$ Syafaruddin Dkk, Administrasi Pendidikan, 77.
} 
Salah satu upaya Ibu Ratini sebagai pengawas bahwa ia selalu memposisikan delapan SNP harus terpenuhi di setiap madrasah. Madrasah berhak memiliki kelayakan standar nasional, mengingat madrasah sebelum memasuki era reformasi masih di pandang "kelas dua" dan memiliki tingkat kepercayaan masyarakat yang rendah dibandingkan sekolah umum. ${ }^{45}$ Pemantauan delapan SNP menjadi penting bagi pengawas, mengingat di antara delapan SNP seperti standar proses dan standar sarana prasarana harus terpenuhi. Upaya pemantauan delapam SNP yang dilakukan Ibu Ratini membuahkan hasil, terdata pada peningkatan sarana dan prasarana di MI Al Islam Sendiri mengalami peningkatan dari tahun 2015 sampai 2019. Salah satu pemerhatian sarana prasarana oleh pengawas di MI Al Islam seperti bahan ajar guru, pedoman pengajar guru, perlengkapan belajar siswa seperti seragam, buku pedoman belajar dan penambahan komputer di ruang tata usaha terlihat meningkat secara signifikan. Mengingat MI Al Islam sendiri masih baru 'belia' maka standar sarana prasarana terlebih dahulu yang menjadi tolak ukur oleh pengawas.

Peningkatan yang terjadi juga pada masyarakat sekitar untuk menyekolahkan putra putrinya di MI Al Islam. Pihak madrasah mencatat pada tahun 2017 penerimaan murid baru biasanya hanya berjumlah 37 kurang lebih, namun pada tahun 2019 terjadi peningkatan, murid baru yang diterima MI Al Islam menjadi 77 murid. Pengawas juga menekankan pada pihak humas di MI Al Islam agar selalu update memberikan informasi yang menarik perhatian masyarakat pada MI Al Islam sendiri, sehingga tingkat kepercayaan masyarakat bukan hanya melihat dari sarana dan prasarana yang ada, namun bila dilihat secara eksplisit kreativitas humas di MI Al Islam dalam menawarkan jaminan madrasahlah yang menjadi ketertarikan masyarat. Lebih kreatif lagi apabila pengawas kota Yogyakarta dan kepala madrasah MI Al Islam mengetahui teknik pemasaran pendidikan yang ideal. Seperti tawaran konsep pemasaran pendidikan menurut Ara Hidayat dan Imam Machali sebagai berikut.

Gambar 5

Konsep inti pemasaraan

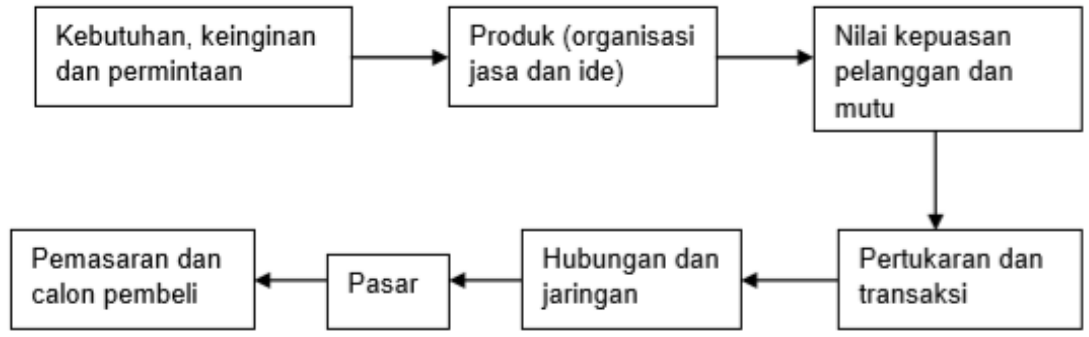

\footnotetext{
${ }^{45}$ Wahyu Iskandar, “Analisis Kebijakan Pendidikan Dalam Perspektif Madrasah”, Jurnal Ilmiah Pendidikan Madrasah Ibtidaiyah 4, no. 1 (2019): 1-22.
} 
Gambar ini menjelaskan bahwa seseorang yang mencari satu atau lebih calon pembeli yang akan terlibat dalam pertukaran tersebut. Calon pembeli 'masyarakat' adalah seseorang yang diidentifikasikan oleh pemasar sebagai orang yang mungkin bersedia dan mampu terlibat dalam pertukaran tersebut. ${ }^{46}$ Sehingga dengan hadirnya konsep ini pengawas dan kepala madrasah lebih di mudahkan dalam seni pemasaran MI Al Islam agar masyarakat dominan berkeinginan menyekolahkan putra putrinya di MI Al Islam. Selanjutnya pada tahun 2017 terjadi polemik pada pembangunan madrasah. Beberapa kali dalam pertemuan supervisi manajerial pengawas selalu meminta pihak madrasah agar meningkatkan ruang belajar. MI Al Islam sendiri belum memenuhi syarat SNP pada sarana prasarana dikarenakan jumlah ruang belajar masih kurang seperti ruang kelas 6 yang saat itu belum ada. Alasan pihak yayasan bahwa pembangunan ruang kelas 6 belum saatnya untuk di bangun, sebab pada tahun 2017 murid MI Al Islam masih pada angkatan ke 5. Hal ini yang menjadi polemik antara pengawas, kepala madrasah dan yayasan. Pada dasarnya yang paling mengerti pada perkembangan madrasah adalah kepala madrasah. Oleh karenanya kepala madrasah berhak menentukan kebijakan konstruktif terhadap perjalanan manajemen madrasah. Problem yang terjadi adalah pihak yayasan tidak memilki sikap egaliter dan cenderung otoriter. Kepala madrasah beberapa kali rapat internal bersama pihak yayasan meminta agar pembangunan kelas 6 segera dilaksanakan, namun gugatan itu tidak direspon aktif oleh pihak yayasan. Pihak yayasan berargument kuat bahwa untuk 2017/2018 fokus pada pemberdayaan panti dan pembangunan SMP Al Islam. Di sinilah problem Ibu Retna Zumiatun sebagai kepala madrasah bahwa ia merasa tidak memiliki otoritas lebih terhadap ide pembangunan madrasah.

Mencermati realitas tersebut, Ibu Ratini sebagai pengawas sangat memberikan kewajaran pada pihak madrasah. Hal ini dikarenakan sudah menjadi permasalahan yang lumrah bagi madrasah swasta ditambah lagi madrasah berada dalam payung hukum yayasan, meskipun tidak menutupkemungkinan pada kewajiban tertentu madrasah harus mengikuti aturan pemerintah seperti kemenag dan dinas pendidikan. Pemantauan SNP pada aspek sarana dan prasarana pada di MI Al Islam pada laporannya 2019 ternyata mengalami perkembangan. Pada polemik yang terjadi pihak yayasan menyadari bahwa pembangunan kelas tambahan memang penting untuk segera berdiri. Pada sebab itulah ketika pemantauan sarana prasarana 2019 di MI Al Islam oleh Ibu Ratini terlihat memiliki perubahan. Terdata pada tahun 2020 pembangunan tambahan kelas bertambah.

Sebagai lembaga pendidikan yang masih baru, MI Al-Islam Giwangan telah memiliki gedung yang cukup memadai untuk menyelenggarakan kegiatan pendidikan. Gedung MI Al-Islam, yang saat ini masih berada dalam tahap pembangunan dan pengembangan, telah mencapai tahap finishing di beberapa tempat sekitar 90-95\%. Artinya, secara garis besar gedung baru MI Al-Islam

\footnotetext{
${ }^{46}$ Ara Hidayat dan Imam Machali, Pengelolaan Pendidikan (Yogyakarta:Kaukaba, 2012), 2-7.
} 
Giwangan sudah bisa di gunakan untuk melaksanakan kegiatan belajarmengajar. ${ }^{47}$ Terdapat juga ruang perpustakaan yang menjadi satu dengan UKS, kantin/koperasi, musala, perpustakaan, laboratorium, dan lain sebagainya.

Tabel 2

Daftar nama bangunan gedung MI Al-Islam ${ }^{48}$

\begin{tabular}{|c|c|c|c|c|c|}
\hline N & \multirow{2}{*}{ RUANG } & \multirow{2}{*}{ JML } & \multicolumn{3}{|c|}{ KONDISI } \\
\cline { 4 - 6 } $\mathrm{O}$ & & & Baik & Sedang & Rusak \\
\hline 1 & Ruang Kepala Sekolah + Guru & 1 & $\sqrt{ }$ & - & - \\
\hline 2 & Ruang Kelas & 6 & $\sqrt{ }$ & - & - \\
\hline 3 & Ruang Perpustakaan + UKS & 1 & $\sqrt{ }$ & - & - \\
\hline 4 & Ruang Media & 1 & $\sqrt{ }$ & - & - \\
\hline 5 & Ruang Kegiatan & 1 & $\sqrt{ }$ & - & - \\
\hline 6 & Ruang Komputer & 1 & - & $\sqrt{ }$ & - \\
\hline 7 & Ruang Kantin & 1 & - & $\sqrt{ }$ & - \\
\hline 8 & Gudang & 1 & - & $\sqrt{ }$ & - \\
\hline 9 & Mushola & 1 & $\sqrt{ }$ & - & - \\
\hline 10 & WC/kamar Mandi & 3 & $\sqrt{ }$ & - & - \\
\hline
\end{tabular}

Selanjutnya pemantauan SNP pengawas kota Yogyakarta tidak berhenti pada standar sarana dan prasarana madrasah. Kepala madrasah MI Al Islam juga menyampaikan bahwa pada standar kompetensi lulusan juga menjadi perhatian pengawas. Pada program supervisi manajerial Ibu Ratini sebagai pengawas menegaskan kepada kepala madrasah bahwa standar kompetensi lulusan guru-guru harus sesuai dengan bidang ajarnya masing masing. Penegasan ini dilakukan karena dalam mencapai idealitas akreditasi MI Al Islam salah satu syarat yang harus terpenuhi dilihat dari kompetensi lulusan para guru. Menurutnya cara ini sangat ideal untuk madrasah yang masih berkembang atau masih baru dalam percepatan kelayakan kareditasi. Pengawas kota Yogyakarta dalam hal ini selalu memonitoring perkembangan standar kompetensi lulusan dari tahun ke tahun. Hal ini dilakukan karena dalam monitoring pengawas akan mampu membandingkan hasil yang dapat dicapai sehingga jelas perbebedaannya antara input dengan output. Dalam hal ini pengawas kota Yogyakarta secara eksplisit menerapkan Teori model PDCA Deming yang siklus interaktif PDCA (plan-do-check-act) proses pemecahan masalah yang populer dengan Deming cycle, Shewhart cycle. ${ }^{49}$

Adapun monitoring standar kompetensi lulusan para guru yang dilakukan oleh Ibu Ratini adalah menekankan kepada pengajar MI Al Islam harus di dominasi dari lulusan pendidikan yang sesuai dengan bidang ajarnya. Perhatian

\footnotetext{
${ }^{47}$ Wawancara dengan Retna Zumiatun, Kepala MI AL Islam pada tanggal 17 Februari 2020 Pukul 11.30 WIB.

${ }^{48}$ Dokumen administrasi MI Al-Islam Giwangan tahun ajaran 2018/2019 pada tanggal 9 September 2018, Pukul 10.00 WIB.

${ }^{49}$ Direktorat Tenaga Kependidikan, Direktorat Jenderal Peningkatan Mutu Pendidik dan Tenaga Kependidikan, Modul Metode dan Teknik Supervisi (Jakarta: Depdiknas, 2008), 8.
} 
ini agar kualitas guru tercapai seperti apa yang telah di sampaikan Jamil Dkk, bahwa:

"Guru mampu menginstruksi pembelajaran yang memformulasikan fokus pada strategi, minat, keterlibatan, dan pembelajaran dari kegiatan kelas. Di kelas dengan format pembelajaran instruksional berkualitas tinggi, guru melibatkan siswa dalam pembelajaran aktif dengan menyediakan materi yang menarik dan kreatif, mengarahkan anak-anak ke arah tujuan pembelajaran kegiatan kelas."

Kriteria minimum yang diharuskan adalah pengajar yang memiliki strata pendidikan atau strata 1 (S1). Pada tahun 2017 daftar guru guru di MI Al Islam dalam penyampaian kepala madrasah MI Al Islam belum menyesuaikan lulusan. Padasarnya hal ini dilakukan karena keadaan darurat madrasah yang belum mempunyai pengajar mengingat MI Al Islam masih baru pada masa itu. Melihat tuntutan pencapaian SNP kompetensi lulusan guru dan didukung oleh pantauan pengawas pada tahun 2019 terdata guru guru di MI Al Islam sudah menyesuaikan bidang lulusannya atas kebijakan kepala madrasah.

Tabel 3

Data guru dan karyawan di MI Al Islam $2019^{50}$

\begin{tabular}{|c|l|c|c|l|}
\hline No & \multicolumn{1}{|c|}{ Nama } & NIY & $\begin{array}{c}\text { Pendidikan } \\
\text { Terakhir }\end{array}$ & \multicolumn{1}{|c|}{ Jabatan } \\
\hline 1 & Retna Zumiatun, STP & & S1 & Kepala Sekolah \\
\hline 2 & Siti Nurhayati, S.Pd. & & S1 & Guru Kelas 1 \\
\hline 3 & Hj. Sumaryanti & S1 & Guru Kelas 2 \\
\hline 4 & Alfera Anis, S.Pd & & S1 & Guru Kelas 3 \\
\hline 5 & Alfu Sobarudin, S.Pd.I & & S1 & Guru Kelas 4 \\
\hline 6 & Faqih Utsman & & S1 & Guru Kelas 5 \\
\hline 7 & Dinda Rahmawati, S.Pd & & S1 & Guru Kelas 6 \\
\hline 8 & Riska Desi Nurlaili, S.Sos.I & & S1 & Tata Usaha \\
\hline 9 & Taufik Irawan, S.Th.I & & S1 & Guru Keagamaan \\
\hline 10 & Zumroni S.Pd & & S1 & Guru PJOK \\
\hline 11 & Wahid Rahmatdi, S.Pd.I & & S1 & Guru Keagamaan \\
\hline 12 & Fatchul Aziz, S.Pd. & & S1 & Guru Keagamaan \\
\hline 12 & Samsi, S.Ag & S1 & Guru Keagamaan \\
\hline 13 & Bayu Pamungkas, S.Pd.I & & S1 & Guru Ekstra Karate \\
\hline
\end{tabular}

Data di atas menunjukkan pelaksanaan supervisi manajerial pada pantauan delapan SNP telah terlaksana dengan baik pada tahun 2019. Secara signifikan perubahan terlihat dari kriteria standar sarana dan prasarana sampai kepada standar kompetensi lulusan.

Pada penjelasan sebelumnya telah dipaparkan bahwa yang menjadi prioritas utama pemantauan delapan SNP di MI Al Islam Giwangan oleh

\footnotetext{
${ }^{50}$ Dokumen administrasi MI Al-Islam Giwangan tahun ajaran 2018/2019, Pada tanggal 9 September 2018, pukul 10.00 WIB.
} 
pengawas kota Yogyakarta adalah standar sarana prasarana dan kompetensi lulusan. Namun perhatian pengawas tidak hanya di situ saja. Menurut kepala madrasah MI Al Islam ada beberapa pantauan lain meskipun sifatya hanya instruksi. Seperti persiapan ujian Nasional (UN) dan ujian semester (US), mulai dari persiapan, pelaksanaan sampai evaluasi. Meskipun hanya bersifat instruksi, sebelum hari pelaksanaan UN pengawas memantau terlebih dahulu situasi kesiapan madrasah. Sehingga pada hari pelaksanaan UN dan US sudah terencana dengan baik. Pada hari H pelaksanaan UN Ibu Ratini hadir sebagai peninjau pelaksanaan yang sifatnya melihat situasi yang berjalan. Hal yang sama juga dilakukan oleh Ibu Ratini kepada MIN 1 kota Yogyakarta. Selanjutnya simpulan pada hasil analisis di atas bahwa pelaksanaan supervisi manajerial di MI Al Islam berjalan dengan baik menurut persepsi kepala madrasah MI Al Islam. Dilihat dari sudut pandang kepala madrasah tentang kinerja Ibu Ratini sebagai pengawas, kemudian dibuktikan dari bukti fisik, juga dibuktikan dari keterangan pihak pengawas sendiri.

Sebagai penguat data peneliti mempertegas secara kuantitatif. Pengukuran ini tetap sama atau berjalan simultan melihat persepsi kepala madrasah terhadap kinerja pengawas pada pelaksanaan program. Adapun hasil penyebaran angket yang di lakukan peneliti kepada kepala madrasah MI Al Islam, penulis memaparkan penjelasan di bawah dengan analisa rating scale.

Pernyataan angket ada 4 kriteria jawaban yang harus di isi oleh responden, yakni sangat tidak setuju, tidak setuju, setuju dan sangat setuju. Bila di presentasekan dengan angka maka kategorisasinya buruk sekali, buruk, sedang, baik sekali.

Tabel 4

Hasil persentase jawaban Kepala Madrasah MI Al Islam terhadap pelaksanaan pengawas

\begin{tabular}{|c|c|c|c|}
\hline \multirow{2}{*}{$\begin{array}{l}\text { No. } \\
\text { Item }\end{array}$} & \multirow{2}{*}{ Item Pernyataan } & \multicolumn{2}{|c|}{ MI Al Islam Giwangan } \\
\hline & & Jawaban Alternatif & Persentase \\
\hline 1 & $\begin{array}{l}\text { Pengawas melaksanakan program pembinaan } \\
\text { kepala madrasah }\end{array}$ & 3 & $4,41 \%$ \\
\hline 2 & Pengawas memiliki instrument kepengawasan & 4 & $5,88 \%$ \\
\hline 3 & $\begin{array}{l}\text { Pengawas melaksanakan pemantauan } \\
\text { pelaksanaan delapan SNP }\end{array}$ & 3 & $4,41 \%$ \\
\hline 4 & $\begin{array}{l}\text { Pengawas melaksanakan program penilaian } \\
\text { kinerja kepala madrasah }\end{array}$ & 3 & $4,41 \%$ \\
\hline 5 & $\begin{array}{l}\text { Pengawas melaksanakan bimbingan dan pelatihan } \\
\text { professional kepala madrasah di KKKS/MKKS }\end{array}$ & 3 & $4,41 \%$ \\
\hline 6 & $\begin{array}{l}\text { Pengawas melaksanakan program bimbingan dan } \\
\text { pelatihan kepala madrasah dalam menyusun } \\
\text { program madrasah, rencana kerja, pengawasan } \\
\text { dan evaluasi }\end{array}$ & 2 & $2,94 \%$ \\
\hline 7 & $\begin{array}{l}\text { Pengawas memantau kurikulum madrasah diuun } \\
\text { berdasarkan pengembangan dari kurikulum } 2013\end{array}$ & 3 & $4,41 \%$ \\
\hline 8 & Melaksanakan pemantauan UN dan US & 3 & $4,41 \%$ \\
\hline 9 & Pengawas memantau PSB dan ekstrakurikuler & 3 & $4,41 \%$ \\
\hline 10 & Pengawas menilai kinerja kepala madrasah & 2 & $2,94 \%$ \\
\hline 11 & $\begin{array}{l}\text { Pengawas melaksanakan pembinaan madrasah } \\
\text { dalam persiapan akreditasi }\end{array}$ & 3 & $4,41 \%$ \\
\hline
\end{tabular}




\begin{tabular}{|c|l|c|c|}
12 & $\begin{array}{l}\text { Pengawas menerapkan berbagai inovasi } \\
\text { pendidikan dan pembelajaran }\end{array}$ & 2 & $2,94 \%$ \\
\hline 13 & $\begin{array}{l}\text { Pengawas melaksanakan pemantauan } \\
\text { penyelenggaraan administrasi madrasah }\end{array}$ & 3 & $2,94 \%$ \\
\hline 14 & $\begin{array}{l}\text { Pengawas memantau, menilai dan membina agar } \\
\text { pengelolaan pendidikan memenuhi tuntunan } \\
\text { permendiknas NO. 19/2002 tentang standar } \\
\text { pengelolaan pendidikan dan tata tertib } \\
\text { administrasi }\end{array}$ & 3 & $4,41 \%$ \\
\hline 15 & $\begin{array}{l}\text { Memantau, membina dan menilai sesuai } \\
\text { pemenuhan tuntutan permendiknas No. 24/2007 } \\
\text { tentang standar sarana dan prasarana }\end{array}$ & 2 & $2,41 \%$ \\
\hline 16 & $\begin{array}{l}\text { Pengawas melaksanakan bimbingan dan } \\
\text { penelitian madrasah }\end{array}$ & 3 & $4,41 \%$ \\
\hline 17 & $\begin{array}{l}\text { melaksanakan pembinaan terhadap kepala } \\
\text { madrasah dalam perencanaan pengembangan } \\
\text { madrasah yakni membimbing merumuskan visi } \\
\text { dan misi madrasah }\end{array}$ & \multicolumn{2}{|c|}{ JUMLAH } \\
\hline
\end{tabular}

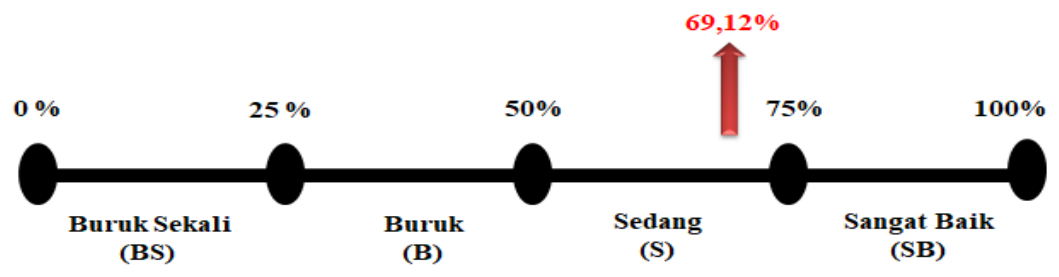

\section{Persepsi Kepala Madrasah terhadap Evaluasi Supervisi Manajerial Pengawas Madrasah Ibtidaiyah}

Penyusunan laporan hasil dan evaluasi pengawas di MI Al Islam dengan tujuan yang sama, yaitu untuk memberikan gambaran terhadap pelaksanaan setiap butir kegiatan supervisi, memberikan gambaran mengenai kondisi madrasah binaan berdasarkan hasil-hasil pengawasan akademik maupun manajerial berupa hasil-hasil pembinaan, pemantauan, dan penilaian, menginformasikan setiap pelaksanaan. Adapun tahapan pelaksanaan laporan meliputi pelaksanaanpelaksanaan seperti mengklasifikasi hasil data monitoring dan bimbingan, membuat analisis hasil data pada pembinaan dan pemantauan, menyusun segala bentuk laporan yang dihasilkan dari proses kepengawasan secara sistematis. Terakhir penyerahan laporan semester dan tahunan kepada Pokjawas dan Kemenag Kota Yogyakarta.

MI Al Islam sendiri mendapat perhatian yang sama oleh pengawas. Hal ini dibuktikan dari serangkaian kegiatan pelaksanaan program kemudian pada akhir semester mencatat apa saja yang menjadi PR dari MI Al Islam. Ibu Retna Zumiatun selaku kepala madrasah mengatakan bahwa pada tahap evaluasi pengawas mengklasifikasi seluruh hasil programnya dan meminta kepala madrasah untuk terus memantau perkembangan administrasi MI Al Islam sendiri. Menurut kepala madrasah juga dalam tahap evaluasi pemerhatian lebih 
yang dilakukan oleh pengawas adalah pada evaluasi delapan SNP. Mengingat pada aspek sarana dan prasarana di MI Al Islam menjadi problem besar yang di temukan pada pelaksanaan program supervisi manajerial. Terlebih sarana dan prasarana di atur oleh Permendiknas no 24 tahun 2007 tentang standar sarana prasarana. Selain itu evaluasi program supervisi manajerial yang dilaksanakan di MI Al Islam bertujuan untuk menilai pola kerja dan manajemen madrasah apakah tercapai sesuai rencana dan kegiatan supervisi. Kemudian juga melihat sejauhmana kegiatan madrasah dengan ukuran kemajuan kinerja kepala madrasah dalam menjalankan kepemimpinannya, sampai kepadamenyesaikan permasalahan yang terjadi di MI Al Islam pada aspek administrasi tanpa ada penyimpangan dari tujuan yang telah ditetapkan.

Menurut kepala madrasah MI Al Islam bahwa pada saat evaluasi pengawas berfokus kepada manajerial madrasah. Pengawas melihat bahwa madrasah MI Al Islam harus lebih diperhatikan pada bidang manajerial. Sebab MI Al Islam masih baru dan harus memiliki manajemen administrasi yang jelas. Pada tahap evaluasi pengawas memakai teknik quality control (QC). Kualitas kontrol bertujuan untuk memastikan kualitas mutu sesuai dengan sasaran yang dicapai, sehingga pengawas mengetahui perkembangan dan memiliki solusi yang akan direncanakan terhadap hasil yang di dapat pada evaluasi. ${ }^{51}$ Pengawas memberikan masukan dan saran setelah pelaksanaan program supervisi manajerial selesai dilaksanakan di MI Al Islam. Masukan itu berupa motivasi kerja kepala madrasah, guru guru dan staf madrasah. Pada Evaluasi delapan SNP pengawas melakukan pengecekan laporan dan instrumen pelaksanaan. Hal ini dilakukan agar laporan sesuai dengan pelaksanaan yang dilaksanakan.

Mencermati realitas di atas, bahwa Ibu Ratini sebagai pengawas telah melaksanakan tanggungawabnya pada tahap evaluasi. Pegawas melakukan quality control pada evaluasi. Hasil yang ditemukan pengawas menurut kepala madrasah MI Al Islam pada tahap evaluasi belum tercapainya delapan SNP pada aspek sarana dan prasarana sehingga pengawas memberikan masukan dan strategi kepada pihak madrasah. Namun pada evaluasi lainnya pengawas sangat profesional dengan menyusun laporan perencanaan dan pelaksanaan program supervisi manajerial. Menurut kepala madrasah MI Al Islam tidak satu pun laporan program yang di manipulasi pengawas, sehingga pengawas melaporkan tugasnya di kemenag sesuai dengan hasil data lapangan yang ada.

Pada pernyataan angket ada 4 kriteria jawaban yang harus di isi oleh responden, yakni sangat tidak setuju, tidak setuju, setuju dan sangat setuju. Bila dipresentasekan dengan angka maka kategorisasinya buruk sekali, buruk, sedang, baik sekali.

\footnotetext{
${ }^{51}$ H. Usman, Manajemen Teori, Praktik, dan Riset Pendidikan (Jakarta: Bumi Aksara. 2010), 520.
} 
Tabel 5

Hasil persentase jawaban Kepala Madrasah MI Al Islam terhadap pelaksanaan pengawas

\begin{tabular}{|c|l|c|c|}
\hline \multirow{2}{*}{ No. Item } & \multicolumn{1}{|c|}{ Item Pernyataan } & \multicolumn{2}{c|}{ MI Al Islam Giwangan } \\
\cline { 3 - 4 } & \multicolumn{1}{|c|}{$\begin{array}{l}\text { Jawaban Alternatif } \\
\text { Pengawas melakukan evaluasi hasil } \\
\text { pelaksanaan program kepala madrasah }\end{array}$} & 3 & $25,00 \%$ \\
\hline 2 & $\begin{array}{l}\text { Pengawas melakukan evaluasi hasil } \\
\text { pelaksanaan program pemantauan delapan } \\
\text { SNP }\end{array}$ & 3 & $25,00 \%$ \\
\hline 3 & $\begin{array}{l}\text { Pengawas melakukan evaluasi hasil } \\
\text { pelaksanaan sesuai pemenuhan tuntutan } \\
\text { permendiknas No. 24/2007 tentang standar } \\
\text { sarana dan prasarana }\end{array}$ & 3 & $25,00 \%$ \\
\hline \multicolumn{1}{|c|}{ Jumlah } & 9 & $75.00 \%$ \\
\hline
\end{tabular}

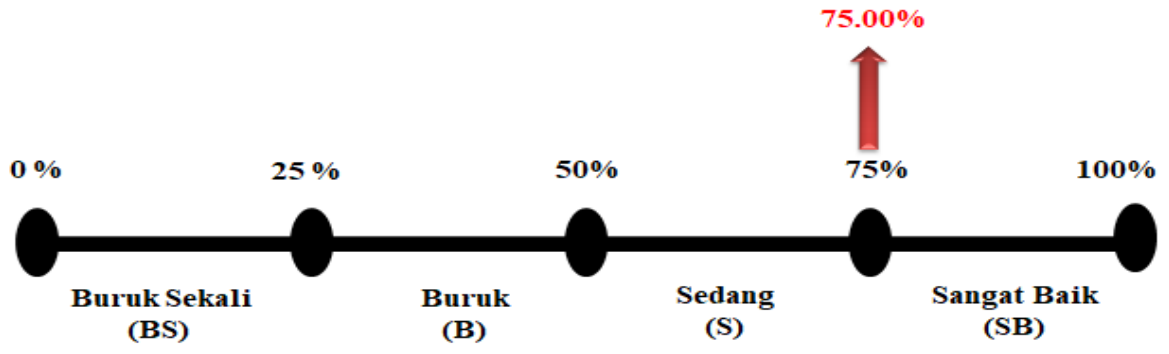

Tabel 6

Keterangan

\begin{tabular}{|l|c|c|c|}
\hline Sangat baik & SB & $\leq$ & $100 \%$ \\
\hline Sedang & S & $\leq$ & $75 \%$ \\
\hline Buruk & B & $\leq$ & $50 \%$ \\
\hline Buruk sekali & BS & $\leq$ & $25 \%$ \\
\hline
\end{tabular}

\section{Kesimpulan}

Dari penelitian tentang persepsi kepala MI Al Islam Giwangan terhadap kinerja supervisi manajerial pengawas madrasah ibtidaiyah di kota Yogyakarta di atas dapat ditarik kesimpulan sebagai berikut. Pertama, kinerja supervisi manajerial dalam perencanaan program pengawas menurut persepsi kepala MI Al Islam Giwangan tergolong kategori sangat baik, dibuktikan dari wawancara dan hasil pengisian instrumen kepala madrasah serta bukti fisik dokumen penyusunan program pengawas. Adapun hasil rata rata skor dalam perencanaan program supervisi manajerial berjumlah $100,00 \%$. Kedua, kinerja supervisi manajerial dalam pelaksanaan program pengawas menurut persepsi kepala madrasah MI Al Islam Giwangan tergolong kategori sedang, dibuktikan dari wawancara dan hasil pengisian instrumen kepala madrasah serta bukti fisik dokumen pelaksanaan program pengawas. Adapun hasil rata rata skor dalam pelaksanaan program supervisi manajerial berjumlah $69,12 \%$. Ketiga, kinerja supervisi manajerial dalam evaluasi program pengawas menurut persepsi kepala madrasah MI Al Islam Giwangan tergolong kategori sedang, dibuktikan dari 
wawancara dan hasil pengisian instrumen kepala madrasah serta bukti fisik dokumen evaluasi program pengawas. Adapun hasil rata rata skor dalam evaluasi program supervisi manajerial berjumlah 75,00\%.[]

\section{Daftar Pustaka}

Abadi, Nur, dkk. Pedoman Supervisi Pengawas Madrasah dan Pengawas PAI Pada Sekolah. Semarang: Kantor Wilayah Kementerian Agama Provinsi Jawa Tengah, 2012.

Alia, Rahmi. "Implementasi Manajemen Peningkatan Mutu Berbasis Sekolah (MPMBS) di Smp Negeri 1 Palembang." (Masters Thesis, Universitas Islam Negeri Raden Fatah, 2019).

Arifin, Hadi Suprapto, Dkk. "Analisis Faktor Yang Mempengaruhi Persepsi Mahasiswa Untirta Terhadap Keberadaan Perda Syariah Di Kota Serang." Jurnal Penelitian Komunikasi Dan Opini Publik 21, no. 1 (2017): 88-101. Arifin, Zainal. "Kepemimpinan Kiai Dalam Ideologisasi Pemikiran Santri Di

Pesantren-Pesantren Salafiyah Mlangi Yogyakarta, Inferensi." Jurnal Penelitian Sosial Keagamaan 9, no. 2 (2015): 351-372.

Arikunto, Suharsimi, dan Lia Yuliana, Manajemen Pendidikan. Yogyakarta: Aditya Media, 2008.

Clay, Lindgren Henry. An introduction as Social Psychology. United States Of America, 1981.

Covey, S. R. The 7 Habits of Highly Effective People. Jakarta: Gramedia, 1997. Direktorat Tenaga Kependidikan, Direktorat Jenderal Peningkatan Mutu Pendidik dan Tenaga Kependidikan. Modul Metode dan Teknik Supervisi. Jakarta: Depdiknas, 2008.

Fitra, Reni Ayu. "Pelaksanaan Fungsi Kelompok Kerja Kepala Sekolah Dasar

Negeri Kecamatan Koto Tangah Kota Padang." Jurnal Bahana Manajemen Pendidikan 1, no. 1 (2013): 19-31.

Gunawan, Ary H. Administrasi Sekolah. Jakart: Rinekacipta, 2011.

Haningsih, Sri. "Peran Strategis Pesantren, Madrasah dan Sekolah Islam di Indonesia." Jurnal El Tarbawi 1, no. 1 (2008): 27-39.

Hanum, Zulia. "Pengaruh Persepsi Pengusaha Kecil Atas Informasi Akuntansi

Keuangan Terhadap Keberhasilan Perusahaan." Jurnal Riset Akuntansi dan Bisnis 13, no. 2 (2013): 217-250.

Hartono, Yudi. "Pendidikan dan Kebijakan Politik (Kajian Reformasi

Pendidikan Di Indonesia Masa Orde Lama Hingga Reformasi." Jurnal Sejarah dan Kemajuannya 6, no. 01 (2016): 35-45.

Hasibuan, Malayu S. Manajemen Sumber Daya Manusia. Cetakan Ketiga. Jakarta: Bumi Aksara, 2001.

Hidayat, Ara, dan Imam Machali. Pengelolaan Pendidikan. Yogyakarta: Kaukaba, 2012.

Howell, J. M. and B.J. Avolio. "Transformational Leadership, Transactional Leadership, Locus of Control, and Support for Innovation: Key Predictors 
of Consolidated-Business-Unit Performance.” Journal of Applied Psychology 78, no. 6 (1993).

Indriyani, Susi, Selvy Mardiana. "Pengaruh Penanganan Keluhan (Complaint Handling) Terhadap Kepercayaan dan Komitmen Mahasiswa Pada Perguruan Tinggi Swasta di Bandar Lampung." Jurnal Bisnis Darmajaya 2, no. 1 (2016): 1-13.

Iskandar, Wahyu, dan Imam Machali. "Persepsi Kepala Madrasah Terhadap Kinerja Supervisi Manajerial Pengawas Madrasah Ibtidaiyah Kota Yogyakarta." Al-Idarah: Jurnal Kependidikan Islam 10, no. 1 (2020): 7693.

Iskandar, Wahyu, dan Muhammad Yusuf, Annisa. "Prototipe Supervisi Pendidikan Dan Kinerja Kepala Sekolah/Madrasah Dalam Rangka Peningkatan Mutu Pendidikan.” Jurnal Islamic Education Manajemen 4, no. 2 (2019): 163-180.

Iskandar, Wahyu. "Analisis Kebijakan Pendidikan Dalam Perspektif Madrasah." Jurnal Ilmiah Pendidikan Madrasah Ibtidaiyah 4, no. 1 (2019): 1-22.

Iskarim, Mochamad. "Rekrutmen Pegawai: Starting-Point menuju Kinerja Organisasi yang Berkualitas dalam Perspektif Manajemen Sumber Daya Manusia dan Islam." Jurnal Manajemen Pendidikan Islam 2, no. 2 (2012): 307-327.

Kementerian Agama RI Direktorat Jenderal Pendidikan Islam. Pedoman Pembinaan Pengawas Madrasah Dan Pengawas Pendidikan Agama Islam Pada Sekolah, 2014.

Lestari, Siti Rokhmi. "Manajemen Pengembangan Dosen Sebagai Upaya Meningkatkan Mutu Sekolah Tinggi Pariwisata Ampta Yogyakarta." Jurnal Media Wisata 12, no. 2 (2014): 87-101.

Machali, Imam. Metode Penelitian Kuantitatif. Yogyakarta: Prodi Manajemen Pendidikan Islam Bekerjasama Dengan Perkumpulan Program Studi Manajemen Pendidikan Islam (PPMPI), 2018.

Majid, Nurcholis. Masyarakat Religius: Membumikan Nilai-Nilai Islam Dalam Kehidupan Masyarakat (Jakarta: Paramadina, 2000), 96-101.

Masaong, Kadim. Supervisi Pembelajaran dan Pengembangan Kapasitas Guru. Bandung:Alfabeta, 2013.

Nanang, Fatah. Landasan Manajemen Pendidikan. Bandung: Remaja Rosdakarya, 2004.

Nurmawati, Nurmawati. "Peran Pengawas dalam Mempersiapkan Akreditasi Madrasah." Semdi Unaya 3, no. 1 (2019): 950-963.

Rozi, M. Asep Fathur. "Strategi Peningkatan Mutu Pendidikan Islam." Edukasi: Jurnal Pendidikan Islam 4, no. 2 (2016): 324-326.

Sahertian, Piet A. Konsep Dasar dan Teknik Supervisi Pendidikan dalam Rangka Pengembangan Sumber Daya Manusia. Jakarta: Rineka Cipta, 2008. 
Sanaky, Hujair. "Paradigma Pembangunan Pendidikan di Indonesia Pasca Reformasi Antara Mitos Dan Realitas." Jurnal Ilmu ilmu Sosial Unisia 62 (2006): 1-18.

Selamet, Mochamad. "Pengaruh Kompetensi Supervisi Manajerial dan Supervisi Akademik Pengawas Sekolah terhadap Kinerja Guru', Jurnal Ilmiah Mahasiswa Pascasarjana Administrasi Pendidikan 2, no. 1 (2014): 73-86.

Slameto. Belajar dan Faktor-Faktor Yang Mempengaruhinya. Jakarta: Rineka Cipta, 2010.

Suhardan, Dadang. Supervisi Profesional. Bandung: Alfabeta, 2010.

Sujanto, Bedjo. Manajemen Pendidikan Berbasis Sekolah: Model Pengelolaan Sekolah di Era Otonomi Daerah. Jakarta: Sagung Seto, 2009.

Supriyanto, Eko. Inovasi Pendidikan, Isu-Isu Pembelajaran, Manajemen, dan Sistem Pendidikan di Indonesia. Solo: Universitas Muhammadiyah Surakarta, 2003.

Syafaruddin, Dkk. Administrasi Pendidikan. Medan:Perdana Publishing, 2016. Syafaruddin, Syafaruddin. Manajemen Mutu Terpadu Dalam Pendidikan Indonesia. Jakarta: Grasindo, 2003.

Tim Pusat Bahasa Departemen Pendidikan Nasional. Kamus Besar Bahasa Indonesia. Jakarta: Balai Pustaka, 2003.

Umar, Munirwan. "Manajemen Hubungan Sekolah dan Masyarakat dalam Pendidikan." Jurnal Edukasi 2, no. 1 (2016): 18-28.

Usman, H. Manajemen Teori, Praktik, dan Riset Pendidikan. Jakarta: Bumi Aksara. 2010.

Walgito, Bimo. Psikologi Sosial: Suatu Pengantar. Yogyakarta: Andi Offset, 2001.

Waluya, Jaka. "Supervisi Pendidikan Pada Sekolah Dasar." Pedagogik: Jurnal Pendidikan Guru Sekolah Dasar 1, no. 1 (2013): 32-42.

Yulistiani, Yustiani. "Kinerja Pengawas Madrasah di Propinsi Daerah Istimewa Yogyakarta." Jurnal Analisa 20, no. 1 (2013): 115-30. 